TAXONOMY AND NOMENCLATURE

\title{
Review of Paraphotina (Mantodea: Photinaidae)
}

\author{
Antonio A. Agudelo ${ }^{1^{*}}$ \& José A. Rafael ${ }^{1}$ \\ 'Programa de Pós-graduação em Entomologia, Coordenação de Diversidade, Instituto Nacional de Pesquisas da \\ Amazônia. Avenida André Araujo 2936, Aleixo, 69067-375 Manaus, AM, Brazil. \\ "Corresponding author. E-mail: ant.agudelo@yahoo.com
}

\begin{abstract}
The number of studies on Neotropical mantises has been growing in recent years, and the systematics of Mantodea is now a dynamic field with noteworthy contributions. Several taxonomic revisions have been published recently. The taxonomy of Paraphotina Giglio-Tos, 1915 is reviewed as part of current studies on systematics of Neotropical Mantodea. Currently, Paraphotina contains four species from South America: P. caatingaensis (Menezes \& Bravo, 2013) comb. nov., P. insolita (Rehn, 1941), P. occidentalis Lombardo, 1998 and P. reticulata (Saussure, 1871). Paraphotina venezuelana Beier, 1963 is a new junior synonym of $P$. insolita. Keys for the Paraphotina species are proposed. The distribution of Paraphotina species is apparently correlates with areas of endemism in the Amazonian and Cerrado regions.
\end{abstract}

KEY WORDS. Amazon, Neotropics, praying mantises, taxonomy.

Taxonomic revisions are an important tool towards a better understanding of the biodiversity, or at least a revalued characterization, of a particular taxon. Studies on Neotropical mantises have been emerging with greater frequency in recent years (RIVERA 2010). The increase in contributions highlights the interest in taxonomic revisions and the continuous emergence of new researchers. The systematic of Mantodea is currently in the process of high-level revision; hence the taxonomic arrangement of large families such as Mantidae and its subfamilies tends to be questionable. Although the first phylogenetic studies supported the groups that had been proposed in the past, for instance Acanthopidae and Thespidae (at least with respect to the Neotropical groups) (Yager \& Svenson 2008, Svenson \& Whiting 2009, Wieland 2013), they have also left some unresolved questions. For example, the phylogenetic relationships of Mantidae, the largest family of Mantodea, remain unresolved. These preliminary phylogenetic studies with a Mantodean focus have demonstrated a way to resolve possible taxonomic conflict using cladistics and probabilistic methods.

Paraphotina Giglio-Tos, 1915 is located within Photinaidae Giglio-Tos, 1915. The Photinaidae species are distributed only in the Neotropical region, specifically in South America, with the exception of Macromantis nicaraguae Saussure \& Zehntner, 1894. The division of Photinainae into two tribes, Photinini and Coptopterygini, introduced by BeIER (1964) was the most widely accepted (Ehrmann 2002, Otte \& Spearman 2005, Agudelo et al. 2007, Ehrmann \& KoçaK 2009). Results from molecular phylogenetic studies (Yager \& Svenson 2008, SvEnson \& Withing 2009) and morphological data (WIELAND 2013) do not support Photinainae sensu BEIER (1964) as monophyletic. Therefore, suprageneric level relationships are currently under investigation with combined morphological and molecular data (A. Agudelo, unpub. data). Despite the paraphyly of Photinaidae (Svenson \& Whiting 2009), the taxonomic validity of its genera appears to not have been questioned, except for Metriomantis Saussure \& Zehntner, 1894, and Photinella Giglio-Tos, 1915 (J. Rivera \& A. Agudelo, pers. obs.). Photinaines are easily identifiable and their diagnostic features allow for the delimitation of sets of species with well-defined patterns. Taxonomic revisions of Photinaidae genera began with the contributions of Heitzmann-Fontenelle (1968), who revised the species of Cardioptera Burmeister, 1838, and TERRA (1995), who reviewed the Neotropical genera and proposed a classification of the subfamily without tribes. LOMBARDo (1999) commented on Metriomantis and described Rehniella (nec HeBARD 1928), current synonym of Photiomantis Piza, 1968 (see Agudelo \& Rivera 2015). Later, Roy (2002) revised Macromantis Saussure, 1871 while Roy \& STIEwe (2011) did the same with Orthoderella Giglio-Tos, 1897.

There are discrepancies among authors about the number of known species of Paraphotina. While Lombardo (1998), Отте \& Spearman (2005), Agudelo et al. (2007) and Rivera (2010) accepted two species based on Cerdá (1992), Terra (1995), Ehrmann (2002) and EHRMANN \& KoçAK (2009) recognized three species. All these proposals have been made without a revisionary study. The objective of this study is to revise Paraphotina species based on type specimens, review material from different localities, and propose a key for proper species identification. 


\section{MATERIAL AND METHODS}

Ninety-eight specimens of Paraphotina from the following collections were examined for comparison (alphabetical list by acronym): ANSP - Academy of National Science of Philadelphia, USA; CEAAVF - Coleção Entomológica Adalbert Antonio Varela Freire, Universidade Federal do Rio Grande do Norte, Brazil; CZMA - Coleção Zoológica de Maranhão, Universidade Estadual de Maranhão, Brazil; CZPB - Coleção Zoológica Paulo Buhrnhein, Departamento de Biologia, Universidade Federal do Amazonas, Brazil; INPA - Instituto Nacional de Pesquisas da Amazônia, Manaus, Brazil; MHNG - Muséum d'histoire naturelle de Genève, Switzerland; MNHN - Muséum national d'Histoire naturelle, France; MPEG - Museo Paraense Emilio Goeldi, Brazil; MZFS - Coleção Entomológica Professor Johann Becker do Museu de Zoologia da Universidade Estadual de Feira de Santana, Brazil; ZMH - Zoologische Museum Hamburg, Germany; ZSM - Zoologische Staatssammlung München, Germany.

Specimens were measured and identified using a stereomicroscope Nikon SMZ645 ${ }^{\circledR}$, photographed using a Leica M205C ${ }^{\circledR}$ and Leica application suite 2010 -Montage ${ }^{\circledR}$. To dissect the male genitalia, the distal portion of the specimen's abdomen was soaked for about 30 minutes in hot water $\left(70^{\circ} \mathrm{C}\right)$. The external genitalia were then removed and dissected using a hypodermic needle. Isolated genital parts were cleared using a warmed $10 \%$ $\mathrm{KOH}$ solution, neutralized with acetic acid, then rinsed and preserved in glycerol. Genital nomenclature follows BEIER (1970). The redescription of the genus was based on all consistent patterns observed in all specimens studied.

\section{TAXONOMY}

Historical overview. Paraphotina Giglio-Tos, 1915 was created based on the unique nominal species Cardioptera reticulata Saussure, 1871 (Fig. 1). The original description of C. reticulata was published in the Memoires de la Société de Physique et d'Histoire Naturelle de Genève in 1871 (SAUssure 1871a: 196), later a reprinted edition from Memoires SPHNG was published by SAUSSURE (1871c), including the XXI tome (SAussure 1871a: 1-214) where C. reticulata had been described. SAUSSURE (1871b) listed two species with the name C. reticulata, the first species described by him in the same year, and second species (M. reticulata Burmeister, 1838) with provisional combination C. reticulata (Burmeister, 1838). In a footnote, SAUSSURE (1871b) makes clear that if Burmeister's species would turn out belong to Cardioptera, the name of his own species need to be changed. Westwood (1889) changed the name of Burmeister's homonymous species to C. burmeisteri. KIRBY (1904a), however, recognized that the nomination by Westwood correspond, it fact, to the second species of the Saussure's list (Burmeister's species), which had priority because is the older available name. He decided to rename Saussure's species to $P$. gracilipes. Currently, Burmeister's species is combined with Photina as $P$. reticulata, so the name given by Saussure should be maintained, thus eliminating the need of the name proposed by KIRBY (1904a). Giglio-Tos (1915) discovered that C. reticulata Saussure is not a representative of Cardioptera nor Photina, thus rejecting the combinations of Westwood (1889) and Kirby (1904a, b). In order to distinguish between $C$. reticulata, Orthoderella ornata Giglio-Tos, 1897 and the species included in Photina, Giglio-Tos (1915) created the genus Paraphotina. Among the diagnostic features he used are shape of pronotum, elevation of the vertex, development of juxta-ocular tubercles, and the size of forefemora which are thinner in C. reticulata than in Photina species. Giglio-Tos (1915) created Photininae to group genera morphologically related to Paraphotina, e.g., Photina, Metriomantis and Photinella, his Photininae also included other groups of genera of the subfamily such as the Coptopteriges-group, the Orthoderellae-group and the Irides-group. Interestingly, his Orthoderellae-group included representatives from Orthoderella but not Paraphotina, a genus which Giglio-Tos (1915) had implicitly stated as being similar to Orthoderella. Later, Giglio-Tos (1919, 1927) transferred Paraphotina to Orthoderellae. Beier (1935) placed Paraphotina within the Photinini, under the large subfamily Mantinae. Subsequently, BeIER $(1964,1968)$ revalidated this group back to subfamily status, but transferred Paraphotina from Photinini to Coptopterygini. In his revisionary work of Neotropical genera, TerRa (1995) redescribed Paraphotina within Photininae (without tribes), drawing attention to the nomenclatural status of the name Photininae, which was pre-occupied by a firefly genus of Lampyridae (Coleoptera), the case was reprised and analyzed by SvENSON \& BRANHAM (2007). Ehrmann (2002) reprised the classification of Photininae into two tribes (Photinini and Coptopterygini) and transferred Paraphotina back to Photinini. The classification of EHRMAnN (2002) was followed by several authors (Agudelo \& CHICA 2003, Otte \& Spearman 2005, Agudelo et al. 2007, Ehrmann \& KoçaK 2009), some already using the amended name Photinainae (Rivera 2010, Rodrigues \& CanCello 2013, Roy 2014, François \& Roy 2015). A new proposed classification by Rivera \& Svenson (2016) includes Paraphotina within Orthoderellini.

Beier (1942) was the first to report a female of the genus from Bahia, highlighting the spots on the anterior coxae. BEIER (1963) described Paraphotina venezuelana Beier, 1963 from Maracay, Venezuela, based on a male holotype (Fig. 2) and a female allotype (Fig. 3). CERDÁ (1992) discovered that the specimen described by ReHN (1941) as the holotype of Guaraunia insolitum (type species of Guaraunia) corresponds to a representative of the genus Paraphotina. He also suggested that P. venezuelana and $G$. insolita are synonyms of $P$. reticulata, arguing that differences in size and coloration are just geographical variations of the same species. Apparently, TeRRA (1995) was not aware of the procedure of CERDÁ (1992) and also proposed Guaraunia as a new synonym of Paraphotina without establishing a species-level synonymy. That is, he treated the three species known at the time as valid: $P$. insolita (Guaraunia insolitum), P. reticulata and $P$. venezuelana. 


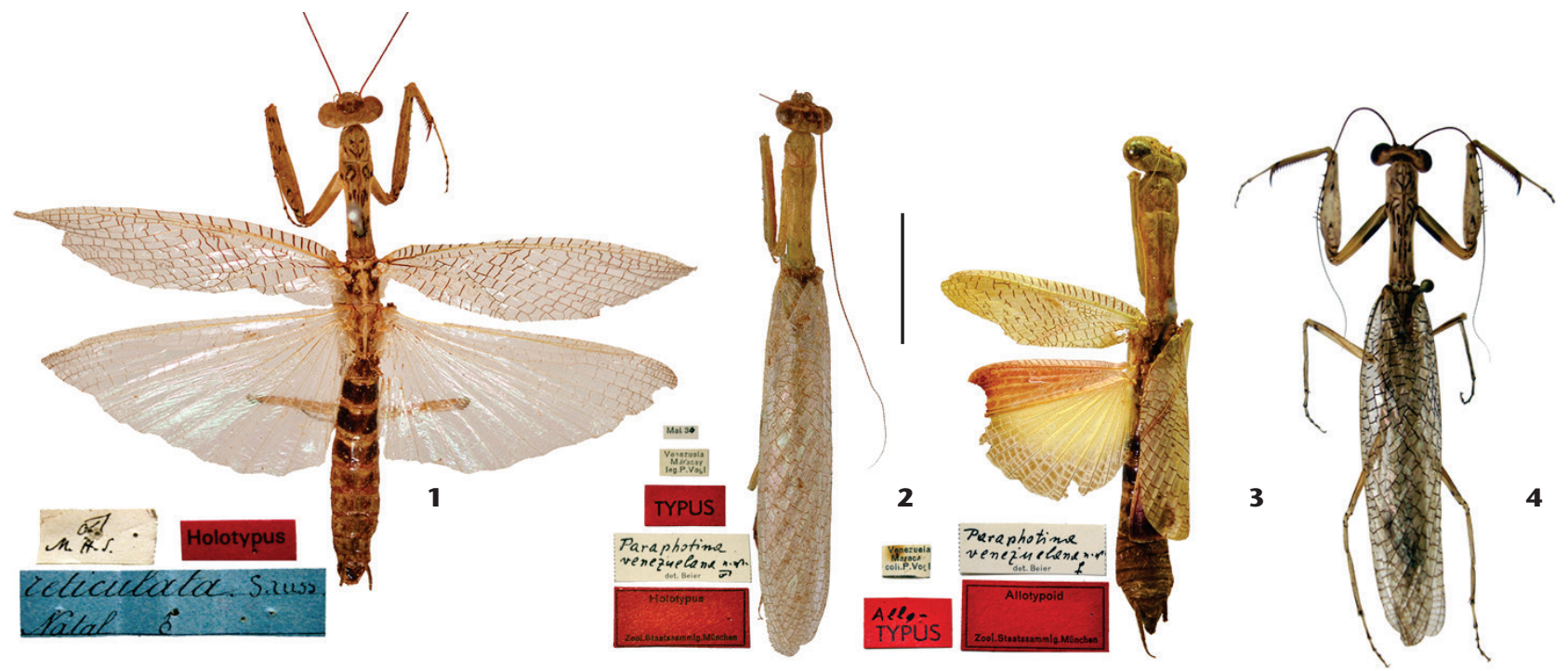

Figures 1-4. Types of Paraphotina (dorsal habitus): (1) Paraphotina reticulata (originally Cardioptera reticulata Saussure, 1871) holotype male deposited in MHNG; (2-3) Paraphotina venezuelana, (2) holotype male, (3) allotype deposited in ZSM; (4) Paraphotina caatingaensis comb. nov. (originally Orthoderella caatingaensis Menezes \& Bravo, 2013) holotype male deposited in MZFS. Arrow highlights the basal spot on fore coxa. Scale bar: $10 \mathrm{~mm}$. Photo of P. caatingaensis courtesy of E. Menezes (MZFS).

Later LOMBARDO (1998) approved the synonymy of Cerdá (1992) and added the description of Paraphotina occidentalis from Peru, leaving Paraphotina with two valid species: $P$. occidentalis and $P$. reticulata. However, EHRMANN (2002) and EHRMANN \& KoçAK (2009) treated $P$. insolita as valid and $P$. venezuelana as a synonym of $P$. reticulata, thus accepting three species for the genus. Recently, Orthoderella caatingaensis Menezes \& Bravo, 2013 has been described from Bahia (Fig. 4). We will show that this species has some features that are not seen in Orthoderella and should be transferred to Paraphotina.

Paraphotina has been morphologically associated with Orthoderella and very likely they are closely related. Although at first glance the general appearance is similar, conserved features in this group of species have confirmed the generic status of Paraphotina, e.g., the weak development of the juxta-ocular tubercles, and the shape of the head and pronotum. The original descriptions of Paraphotina species were well detailed, except for $P$. reticulata. The species currently included in Paraphotina are morphologically homogeneous (Figs. 5-8) the differences between them being very subtle. They essentially concern only the shape of some body parts (Figs. 9-16) and the male external genitalia (Figs. 17-33). We provide a complete redescription of the genus and a diagnosis with comparative figures for each species. Particularities of each species are commented upon in the diagnoses. Unfortunately, the number of available females does not allow us to make a proper review of this sex to be incorporated into the key. Therefore, it has become necessary to use features of the male external genitalia for elaborating the key.

\section{Key for adult males of Paraphotina}

1. Fore coxae without spots 2

$1^{\prime}$. Fore coxae with ventrobasal spot (Fig. 4, arrow)

\section{P. caatingaensis}

2. Body length, from the anterior part of vertex to the apex of the subgenital plate, usually $40 \mathrm{~mm}$, rarely reaching $45 \mathrm{~mm}$. Right membranous lobe (dorsal view) of hypophallus with moderately long setae (Fig. 22), or hypophallus ending in a strongly sclerotized lateral process (Fig. 24, lp).....

2 '. Body length, from the anterior part of vertex to the apex of the subgenital plate, usually greater than $45 \mathrm{~mm}$. Right membranous lobe (dorsal view) of hypophallus with minute setae and without lateral process (Fig. 23) ......P. occidentalis

3. Pseudophallus projected towards dextro-ventrally (dorsal view) (Fig. 18, psph). Hypophallus without lateral process (Fig. 22) . .P. insolita

3 '. Pseudophallus projected towards dextro-dorsally (dorsal view) (Fig. 20, psph). Hypophallus with a strongly sclerotized lateral process (Fig. 24, lp) ...... P. reticulata

\section{Paraphotina Giglio-Tos, 1915}

Paraphotina Giglio-Tos, 1915: 72

= Guaraunia Rehn, 1941 (synonymy by Cerdá 1992).

Type species. Cardioptera reticulata Saussure, 1871: 196 (1871c: 344, reprint), by monotypy.

Redescription. Body pale yellow to yellow-ochre. Length of body (vertex to apex of abdomen) 30-52 mm (Table 1). Head 

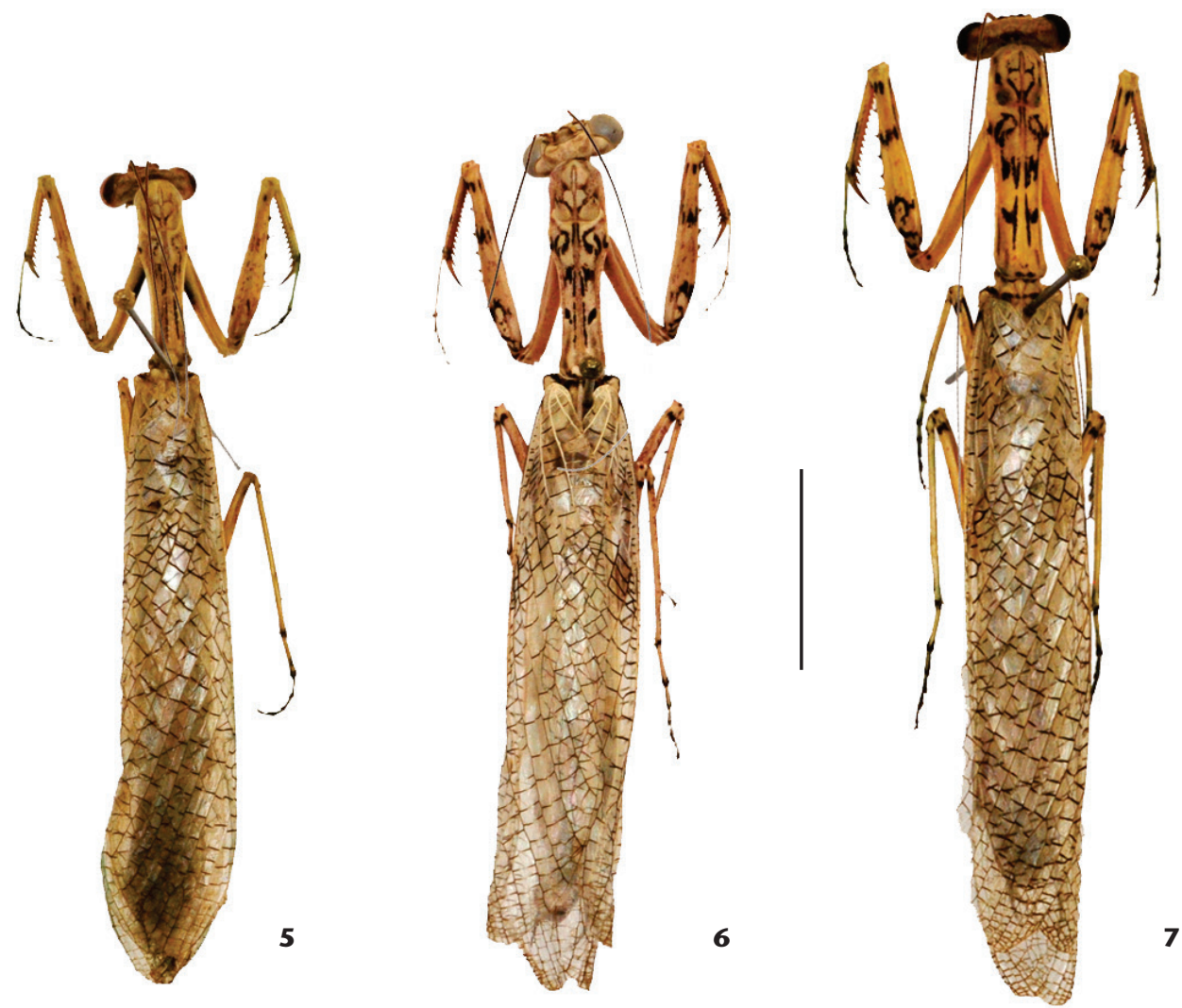

8

Figures 5-8. Males of Paraphotina (dorsal habitus): (5) P. caatingaensis from Bahia, Brazil; (6) P. insolita from Meta, Colombia; (7) P. occidentalis from Coari, Amazonas, Brazil; (8) P. reticulata from Maranhão, Brazil. Scale bar: $10 \mathrm{~mm}$.
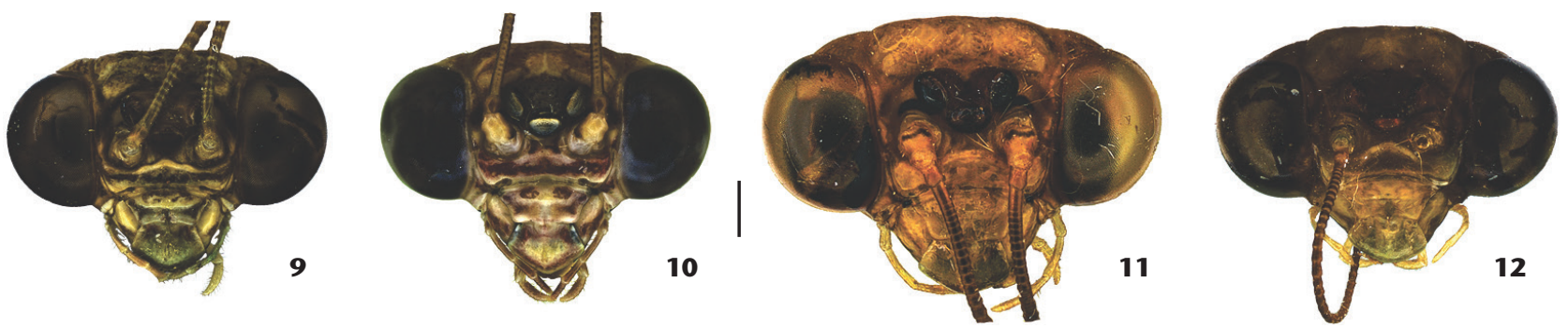

Figures 9-12. Head of males of Paraphotina (frontal view): (9) P. caatingaensis from Bahia, Brazil; (10) P. insolita from Meta, Colombia; (11) P. occidentalis from Coari, Amazonas, Brazil; (12) P. reticulata from Maranhão, Brazil. Scale bar: $1 \mathrm{~mm}$.

elliptical; antennae filiform with scattered short setae, longer than half of body; pedicel and scape clear; vertex convex in frontal view, higher than juxta-ocular tubercles; juxta-ocular tubercles slightly developed; eyes globose (Figs. 9-12); ocellar tubercle pale yellow to dark gray without developed expansions in male; female ocelli located at center of a transversal carina; frontal shield more than three times wider than high, central part of dorsal margin convex. Pronotum with arabesque marks, elongated, smooth; prozona with anterior margin convex, lateral margins subparallel; metazona 2.5 times longer than prozona, with longitudinal carina slightly marked; pronotal terminal tubercle poorly developed with two distal spots, which may be fused (Figs. 13-16). Fore coxae almost as long as metazona. Forecoxae and trochanters smooth, with or without black spots. Fore femora mildly concave dorsally, generally with three spots on anterior surface and arabesque marks in posterior surface; 13-14 anteroventral spines, the even spines generally with black spot at base, rarely at distal odd spines; 5 posteroventral spines, black at base; 3 discoidal spines, second spine with an anterior black spot at base. Fore tibiae usually with three black spots on 

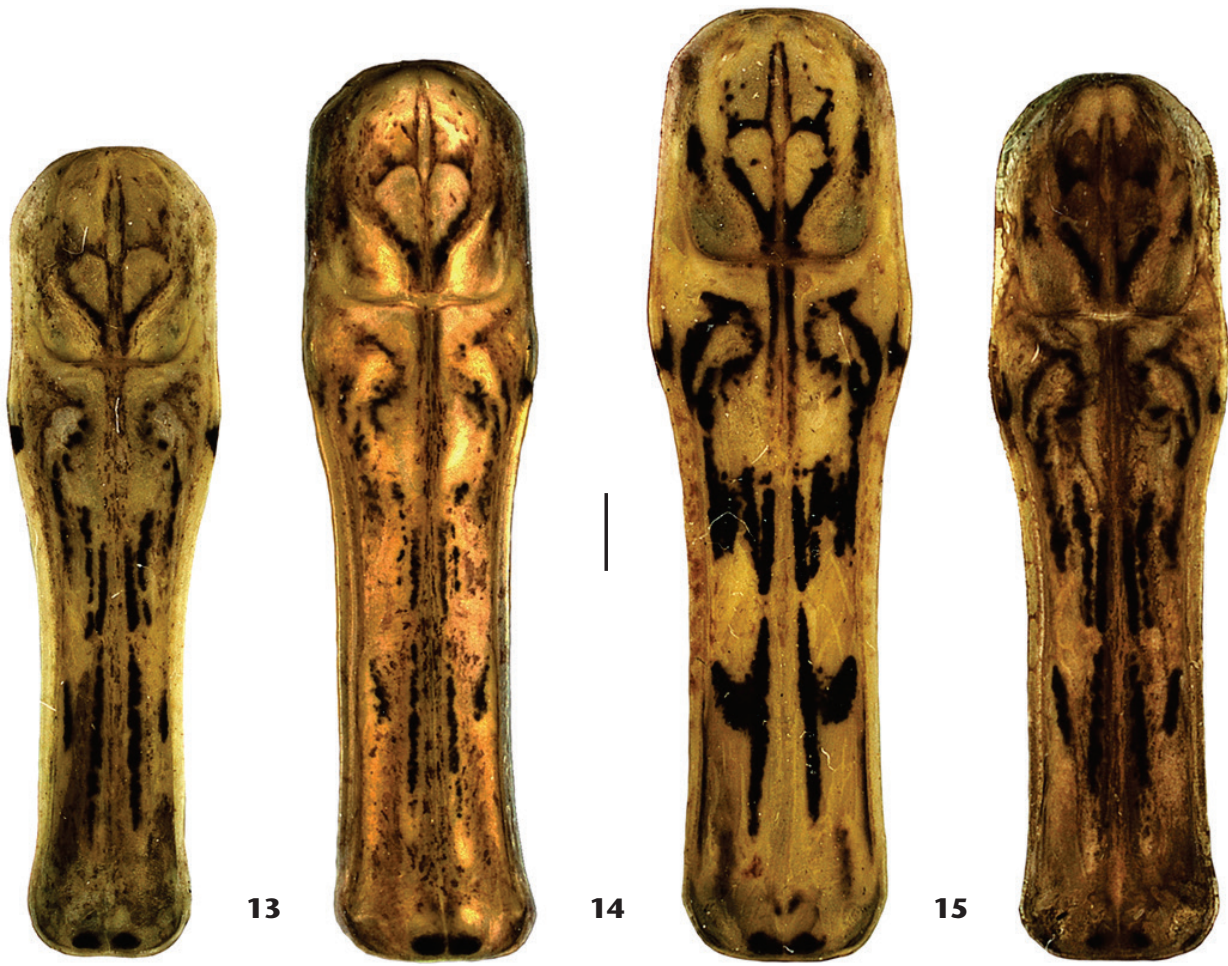

Figures 13-16. Pronota of males of Paraphotina (dorsal view): (13) P. caatingaensis from Bahia, Brazil; (14) P. insolita from Meta, Colombia; (15) P. occidentalis from Coari, Amazonas, Brazil; (16) P. reticulata from Maranhão, Brazil. Scale bar: $1 \mathrm{~mm}$.

Table 1. Comparative measurements of the examined specimens of Paraphotina.

\begin{tabular}{|c|c|c|c|c|c|c|c|c|}
\hline \multirow{2}{*}{ Length } & \multicolumn{2}{|c|}{ P. caatingaensis } & \multicolumn{2}{|c|}{ P. insolita } & \multicolumn{2}{|c|}{ P. occidentalis } & \multicolumn{2}{|c|}{ P. reticulata } \\
\hline & Male $(\mathrm{mm})$ & Female $(\mathrm{mm})$ & Male $(\mathrm{mm})$ & $\overline{\text { Female }(\mathrm{mm})}$ & Male (mm) & Female $(\mathrm{mm})$ & Male $(\mathrm{mm})$ & Female $(\mathrm{mm})$ \\
\hline Body (head to tip of abdomen) & $30.0-39.0$ & 45.0 & $38-40$ & 37.0 & $47.0-52.0$ & - & $36.0-45.0$ & 43.64 \\
\hline Head (vertex to distal margin of labrum) & $3.8-4.0$ & 5.2 & $3.6-3.8$ & - & 4.2-4.7 & - & $3.6-4.2$ & 5.10 \\
\hline Distance between lateral margins of the eyes & $5.0-5.5$ & 7.0 & 5.3-5.5 & - & $6.0-6.8$ & - & $5.0-6.3$ & 6.91 \\
\hline Pronotum & $9.8-11.7$ & 13.5 & $9.0-11$ & 11.0 & $12.6-14.2$ & - & $10.0-12.5$ & 13.67 \\
\hline Prozona & $2.9-3.8$ & 4.3 & $2.2-2.8$ & - & $2.6-3.7$ & - & $3.0-3.5$ & 3.78 \\
\hline Metazona & $6.9-7.9$ & 9.2 & $6.8-8.2$ & - & $10.0-10.5$ & - & $7.0-9.0$ & 9.89 \\
\hline Prothoracic coxae & $6.0-7.5$ & 9.5 & $7.0-7.5$ & 8.0 & $9.0-9.7$ & - & 7.0-9.0 & 9.38 \\
\hline Prothoracic femora & $8.0-9.5$ & 12.0 & $9.0-9.5$ & - & $10.7-11.5$ & - & $8.5-10.5$ & 12.35 \\
\hline Prothoracic tibiae & $4.8-5.0$ & 7.0 & $4.8-5.2$ & - & $6.2-7.0$ & - & $4.5-6.2$ & 7.41 \\
\hline Prothoracic tarsomere I & $3.2-3.5$ & 3.7 & $3.5-4.0$ & - & $4.0-4.2$ & - & $3.0-4.0$ & 4.11 \\
\hline Mesothoracic femora & $6.0-7.0$ & 7.3 & $6.0-7.0$ & - & $8.5-10.0$ & - & $6.5-6.8$ & 7.08 \\
\hline Mesothoracic tibiae & $5.0-6.0$ & 7.0 & $7.0-7.8$ & - & $7.5-8.0$ & - & $6.0-6.8$ & 8.23 \\
\hline Mesothoracic tarsomere I & $1.3-1.6$ & 1.5 & $2.6-3.2$ & - & 2.0 & - & $1.5-2.0$ & 1.64 \\
\hline Metathoracic femora & $6.5-7.5$ & 8.0 & $7.0-8.0$ & - & $9.0-9.5$ & - & $7.0-9.0$ & 9.22 \\
\hline Metathoracic tibiae & $7.0-8.5$ & 10.0 & $9.0-9.5$ & - & $10.0-10.8$ & - & $8.5-10.2$ & 11.85 \\
\hline Metathoracic tarsomere I & $2.0-2.3$ & 2.0 & $2.0-2.3$ & - & $2.5-2.8$ & - & $2.0-2.8$ & 2.63 \\
\hline Mesothoracic wings (base to apex) & $25.5-28$ & 21.0 & $27.0-29.0$ & 15.0 & $35.0-38.8$ & - & $25.5-33.5$ & 21.74 \\
\hline Metathoracic wings (base to apex) & $23.5-26$ & 18.0 & $26.0-27.0$ & - & $34.0-37.5$ & - & $24.5-31.5$ & 18.44 \\
\hline
\end{tabular}

posterior surface; 16-17 anteroventral spines; 13-14 posteroventral spines. All foreleg spines, including tibial claw, darker at tip. Fore metatarsus longer than remaining tarsomeres altogether. Meso and metathoracic femora, tibiae and tarsi setose in male.
Male wings surpassing the tip of abdomen, hyaline, with array of interference colors (wing interference patterns, WIPs by SHEvTsovA et al. 2011). Female wings opaque; mesothoracic wings as long as abdomen, but shorter than the abdomen when at rest above 
it (Figs. 3, 34). Veins of mesothoracic wings almost entirely light brown in males, dark brown in females; venules dark brown, arranged parallel in costal area; stigma hyaline in males, opaque in females. Female with costal area of methatoracic wing pale yellow; apex of discoidal area dark brown, remaining parts ochre or reddish-brown; anal area yellow and subhyaline becoming brownish towards distal end (Fig. 3). Male abdomen subcylindrical (Fig. 1); in female somewhat dilated and ventrally compressed (Fig. 34); both sexes with dark horizontal stripes on first four tergites, less noticeable in T1. Supra-anal plate short and tongue-shaped, shorter than cerci. Cerci (Figs. 34) notably exceeding apex of subgenital plate, conical and laterally compressed. Subgenital plate with left lateral process developed and well sclerotized (Figs. 30-33, llp).

\section{Paraphotina caatingaensis (Menezes \& Bravo, 2013) comb. nov.} Figs. 4, 5, 9, 13, 17, 21, 30

Orthoderella caatingaensis Menezes \& Bravo, 2013: 13. Beier, 1942: 139, female partim; Rodrigues \& Cancello, 2013: 964, partim. Type material: male holotype, male paratype deposited in MZFS.

Diagnosis. Length 30-45 mm. Size small and slender for the genus (Fig. 5). Ocellar tubercle grayish. Pseudophallus short and trapezoidal (Fig. 17, psph). Hypophallus with a strongly sclerotized lateral process, right membranous lobe with moderately long setae (Fig. 21).

Type locality. Brazil (Bahia, Pilão Arcado).

Material examined. All specimens of $P$. caatingaensis comb. nov. from BRAzIL, Bahia: Encruzilhada (850 m) 15³4'35"S, 4058'51"W, 1 male, arm., luz, Rafael JA, Grossi EJ leg.; Maranhão: Mirador (Parque Est. Mirador, Base da Geraldina), 06³7'25"S 4552'08"W, 1 male, 13-19.viii.2012, armadilha luminosa, Santos LL, Pinto JS, Santos LS leg. (INPA); same data but 6 males, 21-26.viii.2006, armadilha luminosa, Limeira de Oliveira F leg. (INPA); same data but 3 males, 07-11.ix.2007, armadilha luminosa, Limeira de Oliveira F, Silva JC leg. (CZMA); same data but 1 male, 07-11.ix.2007, armadilha luminosa, Limeira de Oliveira F, Silva JC leg. (INPA); same data but 8 males, 28.viii-03.ix.2008, armadilha luminosa, Limeira de Oliveira F, leg. (CZMA); same data but 11 males, 28.viii-03.ix.2008, armadilha luminosa, Limeira de Oliveira F leg. (INPA); Mirador (Parque Est. Mirador, Base dos Cágados), 06²48'29"S 4506'34"W, 3 males, Limeira de Oliveira F, Santos AA, Lima TM leg. (CZMA); same data but 2 males, Limeira de Oliveira F, Santos AA, Lima TM leg. (INPA); Minas Gerais: Berizal (Fazenda Veradão), 15³9'54"S, 41³9'56"W, 1 male, 12.xii.2012, Rafael JA, Rossi EJ leg. (INPA); Rio Grande do Norte: Serra Negra do Norte, 5 males, i.2003, Varela Freire AA leg. (UFRN); Parnamirim (Barreira do inferno), 2 females, 20.iv.2011, Araujo JC leg. (UFRN).

Distribution. Brazil (Bahia, Maranhão, Minas Gerais, Piauí, Rio Grande do Norte).

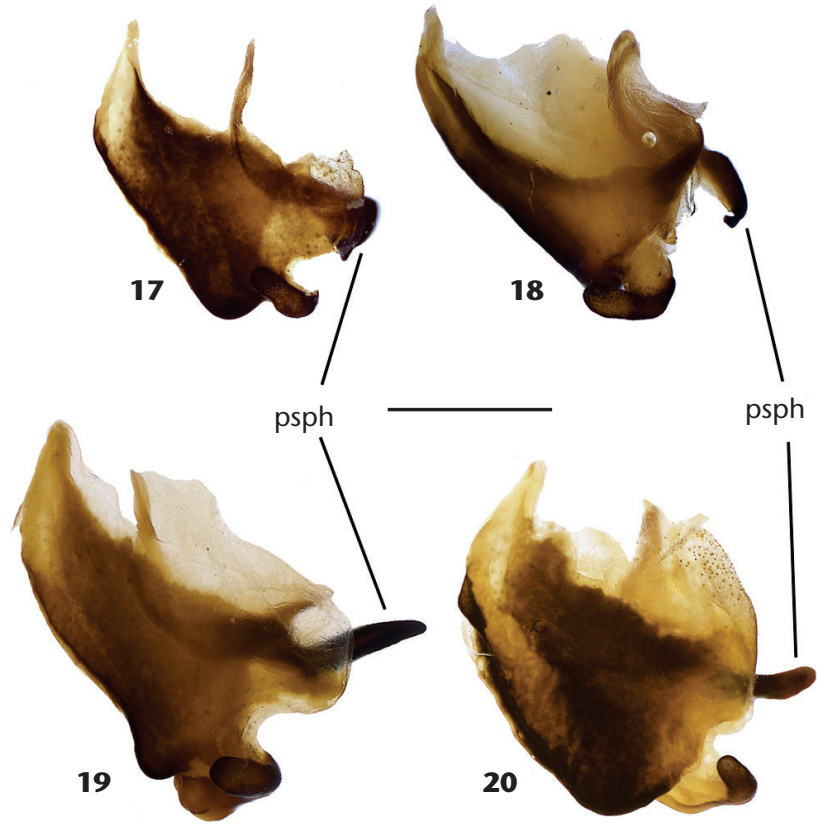

Figures 17-20. External genitalia, left epiphallus of species of $P a-$ raphotina (dorsal view): (17) P. caatingaensis from Rio Grande do Norte, Brazil; (18) P. insolita from Meta, Colombia; (19) P. occidentalis from Coari, Amazonas, Brazil; (20) P. reticulata from Maranhão, Brazil). (psph) Pseudophallus. Scale bar: $10 \mathrm{~mm}$.

Remarks. In the original description of O. caatingaensis, the authors noted that the top of vertex is as high as the juxta-oculars tubercles in frontal view (MENEzEs \& Bravo 2013). This single characteristic does not match one of the main diagnostic features of Orthoderella, which exhibit the vertex with the two juxta-ocular tubercles produced into conical postero-lateral processes much higher than the eyes (Roy \& STIEwE 2011). Therefore, in Orthoderella the top of vertex is concave (in frontal view). The examination of the photograph (Fig. 4) of O. caatingaensis (Eliomar Menezes, pers. comm.), drawings of its phallic complex (Menezes \& Bravo 2013) and additional material from the same region as the type locality established that O. caatingaensis is a representative of Paraphotina. Hence we establish the new combination here.

Perhaps, $P$. caatingaensis comb. nov. is the most easily distinguished species of the genus. The spots on the anterior coxae and the slender appearance of males are remarkable. BEIER (1942) described a female of $P$. caatingaensis comb. nov. from Bahia (identified as $P$. reticulata), reporting the presence of spots on the anterior coxae. However, it appears that these spots are not always present in females of $P$. caatingaensis as opposed to males. The examined females from Rio Grande do Norte (Brazil), which came from a region where only males of P. caatingaensis comb. nov., have been reported so far, do not have these spots. 


\section{Paraphotina insolita (Rehn, 1941)}

Figs. $6,10,14,18,22,31$

Guaraunia insolitum Rehn, 1941: 2. Type material: male holotype deposited in ANSP.

Paraphotina venezuelana Beier, 1963: 7-8, syn. nov.; Terra, 1995: 77. Type material: male holotype (type 5632), female allotype deposited in ZSM.

Paraphotina insolita: Cerdá, 1992, partim; Terra, 1995: 77, partim; Lombardo, 1998: 214, partim; Agudelo \& Chica, 2001, 2003: 135, partim; Ehrmann, 2002; Agudelo, 2004: 49, 58, partim; Otte \& Spearman, 2005: 288, partim; Agudelo et al., 2007: 129, partim; Ehrmann \& Koçak, 2009: 9, partim.

Type Locality. Venezuela (Monagas, Quiriquire).

Diagnosis. Length 38-40 mm. Vertex convex and slightly undulated. Juxta-ocular tubercles slightly developed (Fig. 10). Ocellar tubercle dark gray. Pseudophallus long and projected ventro-dextrally (Fig. 28), rarely with apex curved dorsally (Figs. $18,27)$. Right membranous lobe of hypophallus with moderately long setae (Fig. 22, rml).

Material examined. BraziL, Amazonas: Barcelos, Rio Araçá-Curudurí, $00^{\circ} 05^{\prime} 50^{\prime \prime} \mathrm{N}, 63^{\circ} 17^{\prime 22}$ ”W, 1 male, 15-19.vi.2010, arm., luminosa, Andreazze R, Rafael JA, Takiya D, Agudelo AA leg. (INPA); Roraima: Rio Branco, “Amazonas", 1 male, 30.viii.1924, Bequaert leg., determined as Guaraunia insolitum by JWH Rehn in 1954 (ANSP); Alto Alegre ESEC Maracá, 03²1'59”N, 61²6’04”W, 1 male 12.xii.2015, Boldrini R, Rafael J, Xavier F leg. (INPA); Colombia, Meta: San Martin, Vereda La Pascualera, $200 \mathrm{msnm}$, 1 male, 17.i.2000, t. luz, Agudelo AA, Chica LM (UDFJC); San Martín, Reserva El Caduceo, 1 male, 05.ii.2011, Agudelo AA leg. (INPA). Paraphotina venezuelana: Venezuela, Maracay: 1 male holotype, 1 female allotype; P. Volg leg., Beier det. (ZSM).

Distribution. Brazil (Amazonas, Roraima), Colombia (Meta), Venezuela (Aragua, Monagas).

Remarks. The synonymy established by Cerdá (1992) between Guaraunia insolitum and P. reticulata is rejected here because CERDÁ (1992) only examined material from Venezuela without examining the type specimen of $C$. reticulata, including its phallic complex. This erroneous synonymy was followed by LOMBARDo (1998), who revised the holotype of $G$. insolitum but considered it a representative of $C$. reticulata. The review of the phallic complex of the type specimen of C. reticulata (Figs. 20, 24) and comparison with LOMBARDo's (1998) figures of the phallic complex of the Guaraunia insolitum holotype showed that these species are not synonymous. The specimens of $P$. reticulata present pseudophallus project dextro-dorsally, while in $P$. insolita it is projected to dextro-ventrally. Aside from this, specimens of $P$. insolita lack lateral process on the hypophallus, while $P$. reticulata possesses a well-developed and strongly sclerotized lateral process, projecting to the right (dorsal view). This aspect was corroborated by $P$. insolita material from northern Brazil, Amazonas and Roraima, and the Colombian and Venezuelan "Llanos", also when compared with material of $P$. reticulata from the east of the Amazon. The morphology of the phallic complex of the
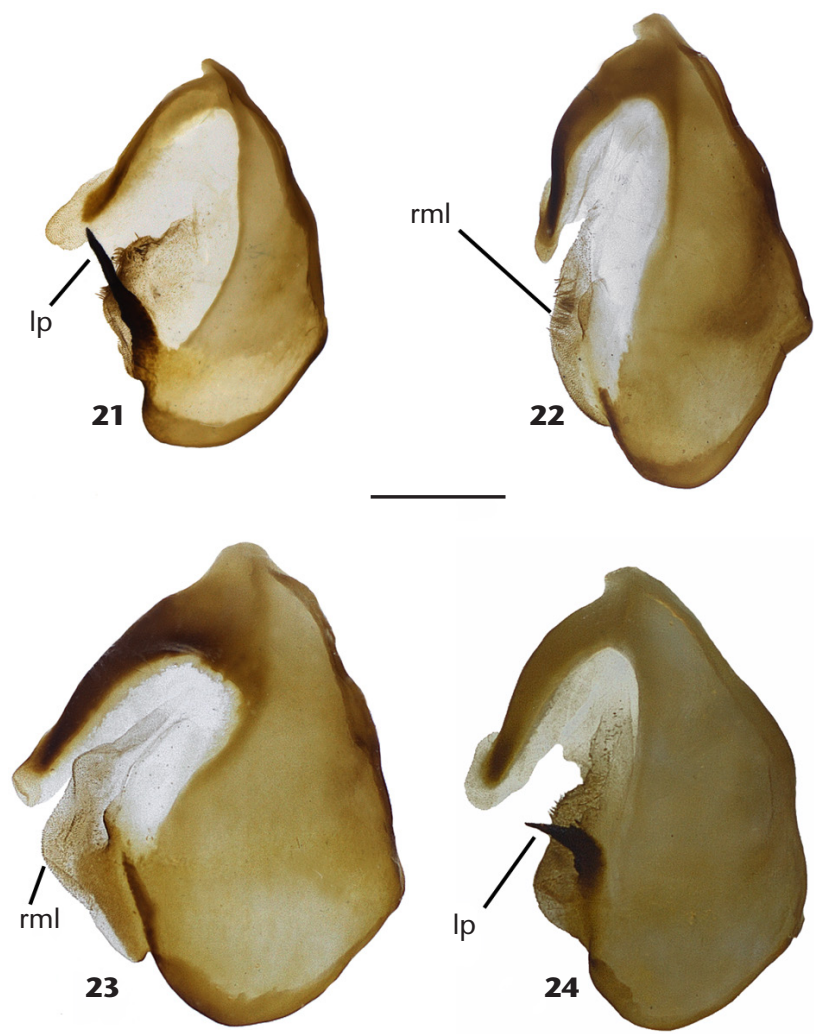

Figure 21-24. External genitalia, hypophallus of species of Paraphotina (ventral view): (21) P. caatingaensis from Rio Grande do Norte, Brazil; (22) P. insolita from Meta, Colombia; (23) P. occidentalis from Coari, Amazonas, Brazil; (24) P. reticulata from Maranhão, Brazil). (lp) Lateral process; $(\mathrm{rml})$ right membranous lobe. Scale bar: $1 \mathrm{~mm}$.

holotype of $P$. venezuelana (Figs. 28,29 ) was found to be very similar to that of $P$. insolita (Figs. 18, 22, see also LombARDo 1998: figs. $4,7,8$ ). In addition, the typical localities of $P$. venezuelana and $P$. insolita are found in the northern Amazon of Venezuela (Fig. 35); Therefore, the synonymy is established.

\section{Paraphotina occidentalis Lombardo, 1998}

Figs. 7, 11, 15, 19, 23, 32

Paraphotina occidentalis Lombardo, 1998: 213; Agudelo \& Chica, 2001: 34; Ehrmann, 2002: 268; Otte \& Spearman, 2005: 287; Agudelo et al., 2007: 129; Ehrmann \& Koçak, 2009: 9. Type material: male holotype, male paratype deposited in ANSP.

Diagnosis. Length 45-50 mm. Robust appearance for the genus (Fig. 7). Ocellar tubercle dark brown. Arabesques on pronotum, forefemora and foretibiae well-marked. Pseudophallus long and projected to the right (Fig. 19, psph). Hypophallus with numerous and minute setae on the lateral membranous lobe (Fig. 23, rml).

Type locality. Peru (Huallaga, Aguaytia). 


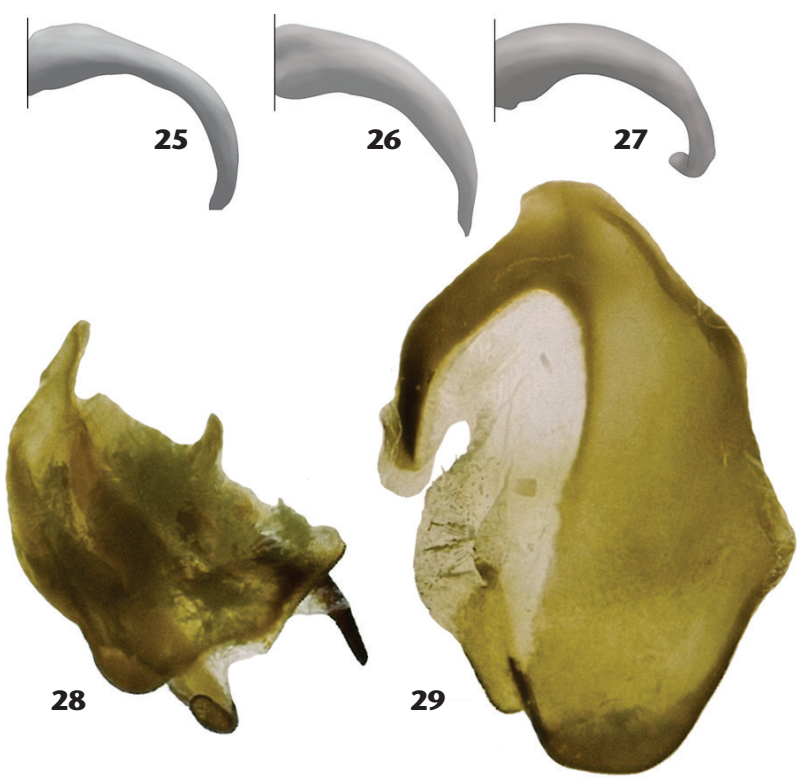

Figures 25-29. Variations in the genitalia of species of Paraphotina: (25-27) P. insolita, pseudophallus, (25) from Meta, Colombia, (26) from Amazonas, Brazil, (27) from Roraima, Brazil. (28-29) P. venezuelana, external genitalia of holotype male, (28) left epiphallus (dorsal view), (29) hypophallus (ventral view). Photos by courtesy of Kai Schütte $(\mathrm{ZMH})$.

Material examined. BrazIL, Acre, (Bujari, Floresta Estadual Antimary), $09^{\circ} 33^{\prime} 67^{\prime \prime} \mathrm{S} 68^{\circ} 32^{\prime} 05^{\prime \prime} \mathrm{W}, 2$ male, 24.viii.2016, armadilha luz mista, Agudelo AA, Rafael JÁ, leg. (INPA). Amazonas (Paq. Nac. do Jaú, Ig. Miratuca), 0157'08”'S 6149'19”'W, 1 male, 14-29.vii.1993, lençol c/luz mista mercúrio, luz negra BL e BLB, Andreazze R, Costa W, Aquino L leg., as Melliera major det. by R Ehrmann (xii 2003) (INPA-0027166); Amazonas (Paq. Nac. Do Jaú, MK médio Jaú- Miriti), 02¹8’S, 64³9’W, 1 male, 05-06. vi.1994, Motta CS leg. (INPA); Amazonas (Uarini), 0302'57"S, 6541'42”W; 1 male, 22.vii-03.viii.1995, Bührnhein P, Aguiar NO leg. (CZPB); Amazonas (Tefé, São Mateus), 04²3'24"S 6540'06"W, 2 males, 07-16.ix.1994, Buhrnhein PF et al., leg. (CZPB); Amazonas (Autazes, Lit-1 AM), 03³2'07"S 59¹3'30"W, 1 male, 21-22.vii.1996, á luz mista de mercúrio, Bührnhein P, Aguiar NO leg. (CZPB); Amazonas (Novo Airão, ramal do Olimpo), 02³9'23"S 6055'44”'W, 2 males, 03-15.vii.1997, sob luz mista de mercúrio, Buhrnhein PF, Aguiar NO leg. (CZPB); Amazonas (Novo Airão, Sitio Carusá, Cominidade Terra Preta), 1 male, 05-07.2010; arm lençol luz mista; Mendes DM et al. leg

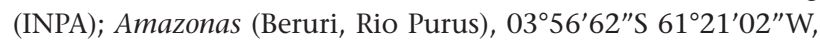
1 male, 30.ix-09.x.2002, armadilha luz mista, Filho FF, Barbosa UC leg. (INPA); Amazonas (Presidente Figueiredo, Est. da Bal-

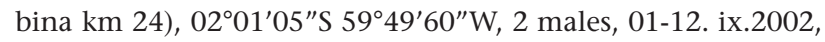
armadilha luz mista, Filho FF, Barbosa UC leg. (INPA); Amazonas (Reserva Extrativista Unini, Rio Unini, Manapana), 0153'18”S $62^{\circ} 27^{\prime} 45^{\prime \prime} \mathrm{W}, 2$ males, 11-12.vii.2004, luz mista de mercúrio,
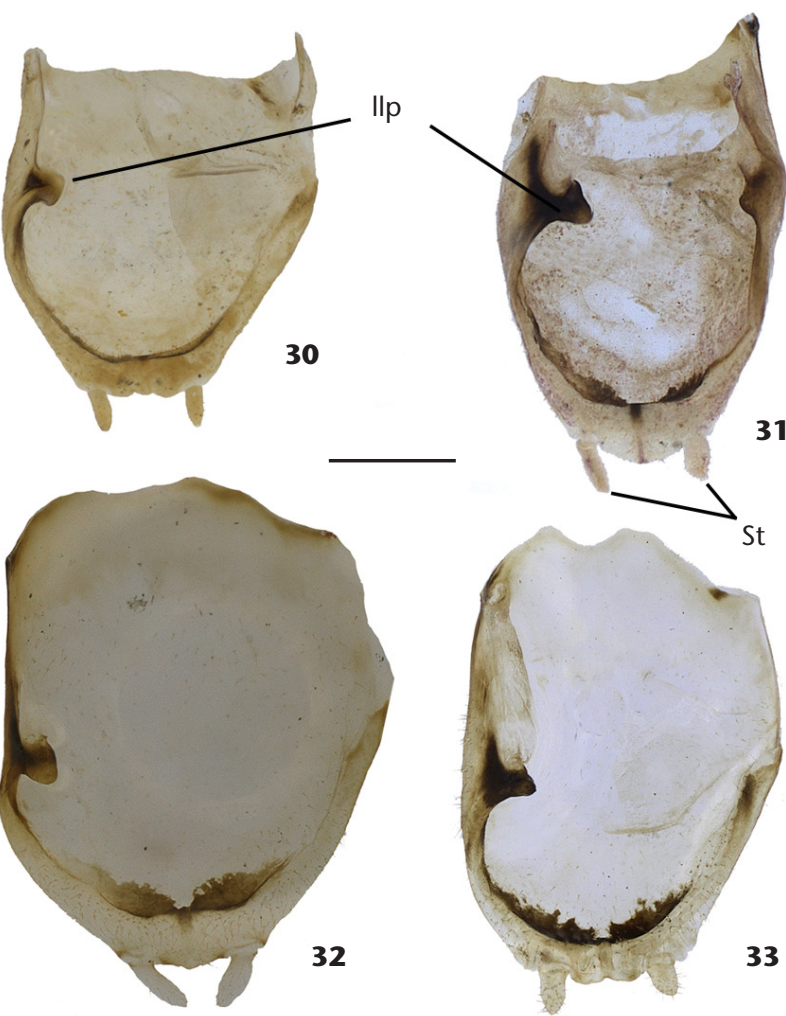

Figures 30-33. External genitalia, subgenital plate of species of Paraphotina (dorsal view): (30) P. caatingaensis from Rio Grande do Norte, Brazil; (31) P. insolita from Meta, Colombia; (32) P. occidentalis from Coari, Amazonas, Brazil; (33) P. reticulata from Maranhão, Brazil. (St) Stylus, (llp) left lateral process. Scale bar: $1 \mathrm{~mm}$.

Filho FF, Barbosa UC leg. (INPA); Amazonas (AM-240, km 24), $02^{\circ} 00^{\prime} 55^{\prime \prime} \mathrm{S} 59^{\circ} 49^{\prime} 40^{\prime \prime} \mathrm{W}, 1$ male, viii.2005, luz mista de mercúrio, Xavier F leg. (INPA).

Distribution. Brazil (Acre, Amazonas), Peru.

Remarks. This species was adequately described by LomBARDO (1998). The appearance of $P$. occidentalis is more robust and the arabesque marks appear sharper. This agrees with the observations of CERDÁ (1992), who found that larger size was correlated with darker spots. The pseudophallus of both Paraphotina occidentalis and $P$. reticulata project dorso-dextrally (dorsal view), but in P. occidentalis the lateral process of ventral phallomere is weakly sclerotized without projecting to the right as in $P$. reticulata.

\section{Paraphotina reticulata (Saussure, 1871)}

Figs. 1, 8, 12, 16, 20, 24, 33, 34

Cardioptera reticulata Saussure, 1871a: 196; 1871b: 75; 1871c: 344 reprinted; Westwood, 1889: 15; Roy \& Cuche, 2008: 17. Type material: male holotype deposited in MHNG.

Photina gracilipes Kirby, 1904a: 86; Kirby, 1904b: 274. 


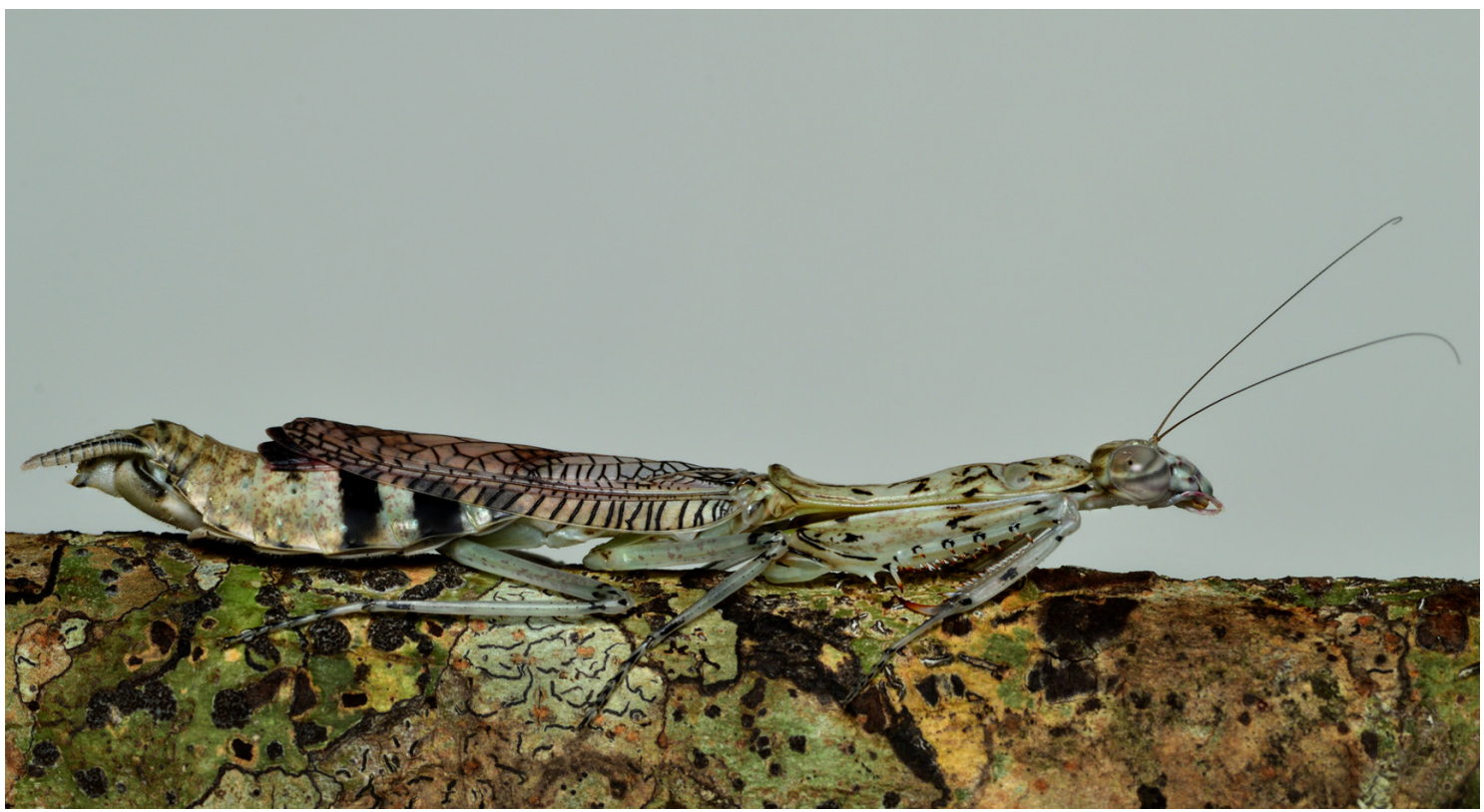

Figure 34. Paraphotina reticulata, alive aspect of a female from Pará, Brazil. Photo courtesy of César Favacho (MPEG).

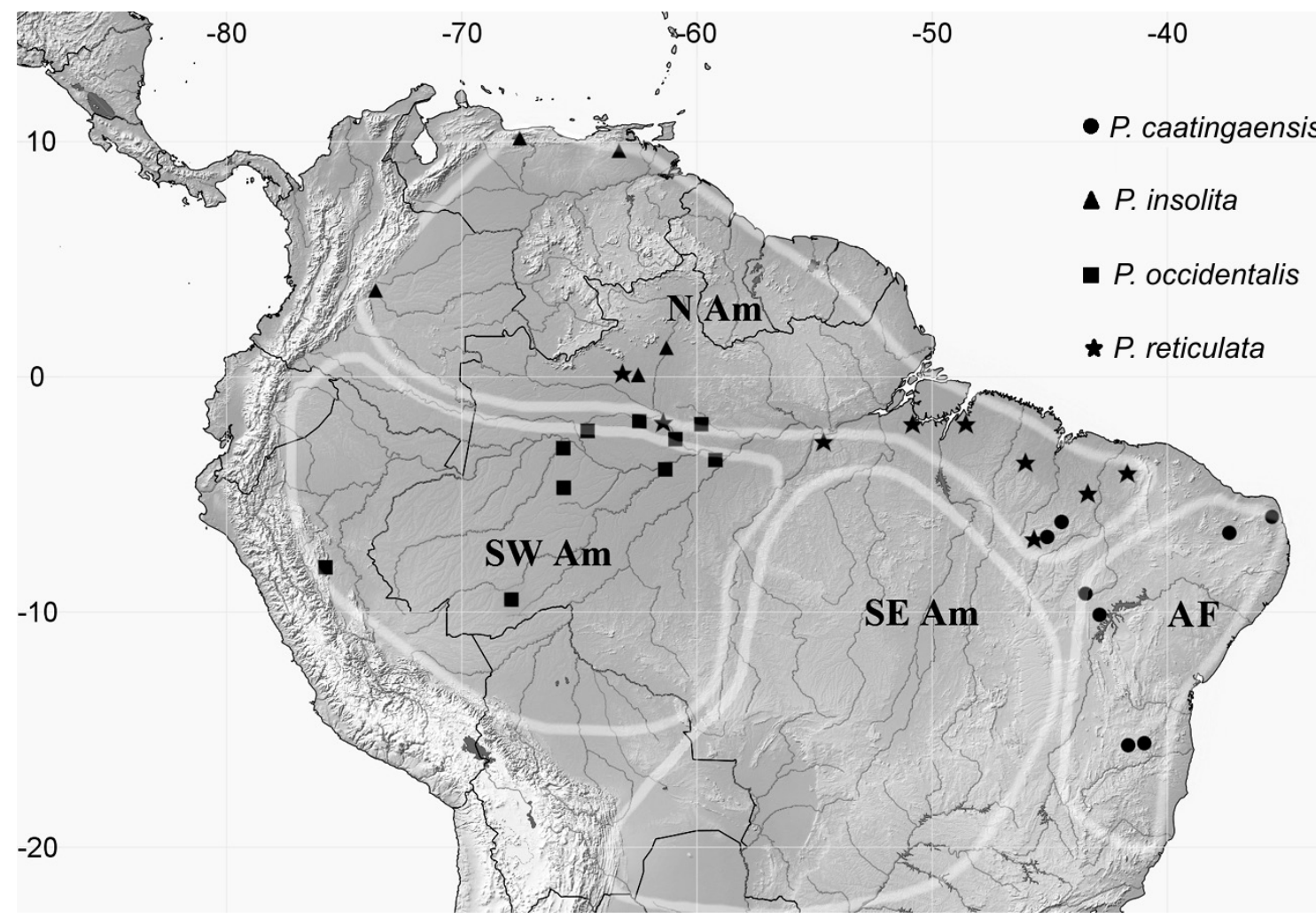

Figure 35. Map of the geographic records for species of Paraphotina with areas of endemism proposed by AmORIM (2009). Note that geographical records of $P$. reticulata include transition areas for each of the other three species. (AF) Atlantic Forest; (N Am) North Amazon; (SE Am) South East Amazon; (SW Am) South West Amazon. 
Paraphotina reticulata Saussure, 1871a: 196; Giglio-Tos, 1915: 72; 1927: 330; Beier, 1930: 28; 1935: 124; Cerdá, 1992: 13, partim; Terra, 1995: 77; Ehrmann, 2002: 268, partim; Otte \& Spearman, 2005: 287; Agudelo et. al., 2007: 129; Ehrmann \& Koçak, 2009: 9.

Diagnosis. Length 36-45 mm. Ocellar tubercle dark. Pseudophallus long and projected to the right (Fig. 20, psph). Hypophallus with a strongly sclerotized lateral process, right membranous lobe with moderately long setae (Fig. 24, rml).

Type Locality. Brazil, Pará.

Material examined. Cardioptera reticulata: Brazil, Pará, holotype male (reticulata Saussure "Natal") (MNHG). Additional material. BRAzIL. Amazonas: Barcelos, Rio Araçá, comunidade Bacuquara, $00^{\circ} 09^{\prime} 17^{\prime \prime} \mathrm{N}, 63^{\circ} 10^{\prime} 35^{\prime \prime} \mathrm{W}, 2$ males, 06.vi.2010, suspensa dossel 25 m; Alvim E, Rafael JA, Agudelo AA leg. (INPA); Novo

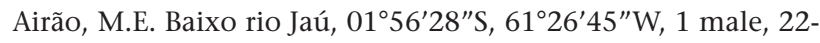
23.vii.1995, luz mista, luz negra, lençol, Motta C, Xavier F leg. (INPA-0027036); Maranhão: Caxias, Reserva Ecológica Inhamum, 2 males, 01-03.xii.2005, Limeira F et. al., leg. (CZMA); same date but Reserva Ecológica Inhamum, Povoado Coités, 1 male, 2224.x.2006, Souza SO, Silva JJ leg. (INPA); same data but1 male, 19-21.i.2007, Souza SO, Silva JJ leg. (INPA); same data but 1 male, 08-11.viii.2008, Limeria F, leg. (INPA); same municipality but Morro do Alecrim, Campus da UEMA), 1 male, 26-30.iii.2009, r. entomológica, Barbosa EA, Neto MB leg. (INPA); Carolina, povoado Canto Grande, Balneario Urupuxete, 3 males, 23-27.ii.2009, armadilha luminosa, Limeira F et al., leg. (CZMA). same data but 2 males, 23-27.ii.2009, armadilha luminosa. Limeira F et al., leg. (INPA); same data but Fazenda Cincorá, 3 males, 17-22.x.2009, armadilha luminosa, Limeira F et al., leg. (CZMA); same data but 1 male, 17-22.x.2009, armadilha luminosa, Limeira $\mathrm{F}$ et al., leg. (INPA); Bom Jardim, REBIO, Res. Biol. Gurupí, 2 males, 15-19.iv.2010, Limeira F et al. leg. (INPA); Parnarama, Povoado Brejo de São Felix, 1 male, 03-06.vi.2010, Souza SS, Lino TR leg. (INPA); Pará: 1 male, holotype (reticulata "Natal") MHS (MHNG); Santo Antonio do Tauá, 2 males, 5-15.x.1979, Michel Boulard leg., genital preparation $\mathrm{n}^{\circ} 3488$ (MNHN); Belém, Campus de Pesquisa do Museu Paraense Emílio Goeldi, 1 female, 10.iii.2014, Favacho C. leg. (MPEG); Piaui: Parque Nacional de Sete Cidades, 04.09909 ${ }^{\circ}$, $41.70952^{\circ} \mathrm{W}, 2$ males, 15-25.iv.2012, Somavilla A, Oliveira leg. (INPA).

Distribution. Brazil (Amazonas, Maranhão, Pará, Piaui).

Remarks. This species had been described with doubtful provenance. The holotype (Fig. 1) of $C$. reticulate bears a label giving the typus locality as Natal (South Africa). However, SAUSSURE (1871a) added a note to the description commenting that the specimen may have come from Pará (Brazil). This comment appeared again in his succeeding work (SAUssure 1871b). We confirmed the State of Pará as type locality due to the conspecific specimens examined are principally from Maranhão and Pará. Cerdá (1992) established $P$. venezuelana as synonym of $P$. reticulata. The comparison between phallic complexes of the holotypes of $P$. reticulata and $P$. venezuelana (Figs. 20, 24, 28,
29) revealed that they are not conspecific, thus the synonymy between these species is rejected here.

\section{DISCUSSION}

Within a morphological context, the definition of most Photinaidae genera has been generally well supported by easily recognizable diagnostic features. Except in cases like Metriomantis, Photina and Photinella, the genera of this family appear to be acceptably defined, but their phylogenetic relationships are not necessarily as clear. After the review of Orthoderella by Roy \& STIEWE (2011), the distinction between Paraphotina and Orthoderella has become more evident. The behavior of Paraphotina species is reminiscent of the observations described by BRUNNER \& GANDOLFo (1990) for females of Orthoderella ornata (per. obs.). However, Orthoderella is distinguished from Paraphotina by a long head with a nearly straight vertex, and by well-developed juxta-ocular tubercles. The pronotum in Orthoderella is slender, its arabesque brands less conspicuous, and the lateral margins of the prozona are nearly parallel. Wings in female Orthoderella are noticeably shorter than the abdomen, exposing its distal half when at rest. In contrast, females of Paraphotina generally expose only the distal third of the abdomen. The genera Orthoderella and Paraphotina are distinguished from other Photinaidae genera by the arabesque marks on their pronotum, forefemora and foretibiae.

The four species of Paraphotina are superficially very similar, which renders their identification somewhat difficult to naked eye. Paraphotina insolita and P. reticulata, in particular, are difficult to distinguish morphologically. The fast identification of $P$. caatingaensis comb. nov. and $P$. occidentalis, is generally less problematic, because their sizes are at opposite ends of the Paraphotina range. Thus, it becomes necessary to resort to a more detailed observation, including the dissection of the genitalia.

While the phylogenetic relationships within Photinaidae are consecutively being analyzed, we are just beginning to understand the life history and systematics of the concerned genera. Some Photinaidae genera such as Metriomantis and Photi$n a$ are in urgent need of revision. Ecological and behavioral data for Paraphotina as well as for the large majority of Photinaidae genera are rare. Behavioral data were studied in Orthoderella by BRunNer \& GANDOlfo (1990) and in Cardioptera brachyptera by TERRA (1992, 1996a, b). Taxonomic approaches are the basis for subsequent evolutionary analysis.

Biogeographical aspects. The distribution of Neotropical species of Mantodea seem to show some patterns similar to those of several others groups studied methodically in the biogeographical context, e.g., Diptera (AMORIM \& PIREs 1996), fitting within subregions and areas of endemism proposed by NiHEI \& CARVALHO (2007). These relationships of the continental northern Neotropical region and its biogeographical components were briefly described by RAFAel \& CUMming (2009), while the biogeographical patterns were discussed by АмовIм (2009). In recent 
reviews of Neotropical Mantodea (Lombardo \& IpPolito 2004, RoY $\&$ Ehrmann 2009, Roy \& Stiewe 2011), the distribution maps of species largely coincided with these classifications (Fig. 35). All species of Paraphotina occur in South America. Three species, $P$. insolita, $P$. occidentalis, and $P$. reticulata, occur in Northwestern Amazonia. Paraphotina insolita is found in North Amazonia (N Am) in Orinoco savannas (Colombia, Venezuela) and Brazil (Roraima and Amazonas, Barcelos). Paraphotina occidentalis occurs mainly in Southwestern Amazonia (SW Am) with records in the municipalities of Bujari (Acre), Novo Airão, Tefé, Autazes, and Beruri (Amazonas), but also with peripheral records in North Amazonia (Presidente Figueiredo). Paraphotina reticulata has been more widely recorded from North Amazonia and Southweastern Amazonia extending until the Atlantic Forest, in Maranhão. Paraphotina caatingaensis has been recorded only in the Brazilian domains of Cerrado and Caatinga, from Maranhão to Minas Gerais. No records from Southeast Amazonia (SE Am) are known to date, but according to the pattern recorded for the known species, it is possible that an unknown species of Paraphotina inhabits this zone. Many questions remain before we will understand the relationships among Photinaidae genera, especially biogeographical aspects and their closer relationship with Neotropical Acanthopidae and Liturgusidae more than Mantidae groups.

\section{ACKNOWLEDGMENTS}

This research was financed with resources from the Conselho Nacional de Desenvolvimento Técnico e Científico (CNPq) through the doctoral scholarship to AAA, (process 156567/2010-5), and Fundação de Amparo à Pesquisa do Estado do Amazonas FAPEAM/PAPAC (286/2013). We are indebted to Peter Schwendinger (MHNG), Dieter Doczkal (ZSM), Klaus Schönitzer (ZSM) and their respective institutions for granting access to type specimens and the entomological collections. To Francisco Limeira (CZMA), Orlando Tobias (MPEG) and Ricardo Andreasse (UFRN) for providing access to material of their respective institutions. We express our gratitude to Kai Schütte (ZMH) and César Favacho (MPEG) who kindly provided important photos and information for this work.

\section{LITERATURE CITED}

Agudelo AA (2004) Mántidos de Colombia (Dictyoptera: Mantodea), p. 43-60. In: Fernández CF, Andrade MG, Amat G (Eds.) Insectos de Colombia. Bogotá, Universidad Nacional de Colombia, Facultad de Ciencias, vol. 3, 604p.

Agudelo AA, Chica LM (2001) Presencia del género Paraphotina Giglio-Tos, 1915 (Mantodea: Vatidae: Photininae) en Colombia. Boletín Científico del Museo de Historia Natural Universidad de Caldas 5: 33-37.

Agudelo AA, Chica LM (2003) Mántidos de la Orinoquía Colombiana: contribución al conocimiento de su diversidad gené- rica y algunos aspectos bioecológicos (Insecta: Mantodea). Revista Colombiana de Entomologia 29: 127-136.

Agudelo AA, Lombardo F, Jantsch LJ (2007) Checklist of the Neotropical mantids (Insecta, Dictyoptera, Mantodea). Biota Colombiana 8: 105-158.

Agudelo AA, Rivera J (2015) Some taxonomic and nomenclatural changes in American Mantodea (Insecta, Dictyoptera) - Part I. Zootaxa 3936: 335-356. doi: 10.11646/zootaxa.3936.3.2

AмоRIм DS (2009) Neotropical Diptera Diversity: richness, patterns, and perspectives, p. 71-97. In: PAPE T, Bickel D, Meier R (Eds.) Diptera Diversity: Status, Challenges and Tools. Leiden, Brill, 459p.

AMORIM DS, Pires MR (1996) Neotropical biogeography and a method for maximum biodiversity estimation, p. 183-219. In: Bicudo CE, Menezes NA (Eds.) Biodiversity in Brazil: A first approach. São Paulo, CNPq, vi+326p.

BEIER M (1930) Ergebnisse einer zoologischen Sammelreise nach Brasilien, insbesondere in das Amazonasgebiet, ausgeführt von Dr. H. Zerny. Annalen des Naturhistorischen Museums in Wien 44: 27-32.

BeIER M (1935) Mantodea. Subfamilie: Mantinae. In: Wytsman P (Ed.) Genera Insectorum. Bruxelles, Fasc. 203, 146p.

Beier M (1942) Neue und seltene Mantodeen aus deutschen Museen. Annalen des Naturhistorischen Museums in Wien 52: 126-154.

BeIER M (1963) Neue und bemerkenswerte Mantiden verschiedener Herkunft. Stuttgarter Beiträge zur Naturkunde, Serie A, 106: 1-11.

BeIER M (1964) Blattopteroidea-Mantodea, p. 850-970. In: BRONN HG (Ed.) Bronn's Klassen und Ordnungen des Tierreichs, Insecta-Arthropoda, Part III. Leipzig, Akademische Verlagsgesellschaft Geest \& Portig K.-G.

Beier M (1968) Mantodea (Fangheuschrecken), p. 1-47. In: Helmcke JG, Starck D, Wermuth H (Eds.) Handbuch der Zoologie. Berlin, Walter de Gruyter \& Co, vol. 4.

BeIEr M (1970) Dictyoptera (Blattoidea et Mantoidea), p. 38-41. In: Tuxen SL (Ed.) Taxonomist's glossary of genitalia in insects. Copenhagen, Munksgaard, 359p.

Brunner D, Gandolfo D (1990) Morphological adaptations to an unusual defensive strategy in the mantid Orthoderella ornata (Insecta: Mantidae). Journal of Zoology 222: 129-136.

CERDÁ FJ (1992) Sinonimia del género Paraphotina Giglio-Tos (Dictyoptera: Mantidae: Photininae). Boletín de Entomología Venezolana 7: 13-17.

EHRMANn R (2002) Mantodea-Gottesanbeterinnen der Welt. Münster, Natur und Tier Verlag, 519p.

EHrmann R, KoçAK AÖ (2009) The Neotropical Mantids (Insecta: Dictyoptera: Mantodea) (Ehrmann 30.v.2009). Cesa News 49: 1-18.

FrançoIs A, Roy R (2015) Le genre Microphotina Beier, 1935: deux espèces, ou une seule? (Mantodea, Photinaidae). Bulletin de la Société entomologique de France 120: 389-396.

Giglio-Tos E (1915) Mantidi esotici. Generi e specie nuove. Bullettino della Società Entomologica Italiana 46: 31-108. 
Giglio-Tos E (1919) Saggio di una nuova classificazione dei Mantidi. Bullettino della Società Entomologica Italiana 49: 50-87.

Giglio-Tos E (1927) Das tierreich. Orthoptera-Mantidae. Berlin, Walter de Gruyter \& Co., 707p.

Hebard M (1928) The group Luzarae of the subfamily Phalangopsinae (Orthoptera, Gryllidae). Transactions of the American Entomological Society 54: 1-56.

Heitzmann-Fontenelle TJ (1968) Revisão dos Mantodea do gênero Cardioptera Burmeister, 1838. Studia Entomologica 12: 245-272.

KIRBY WF (1904a) Notes on Mantidae in the collection of the British Museum, south Ken-sington, with descriptions of new species. Annals and Magazine of Natural History 13: 81-88.

Kirby WF (1904b) A synonymic Catalogue of Orthoptera (Forficilidae, Hemimeridae, Blattidae, Mantidae and Phasmidae). London, British Museum, Natural History, 501p.

Lombardo F (1998) A new species of Paraphotina Giglio-Tos, 1915 from Peru (Insecta: Mantodea). Journal of Orthoptera Research 7: 213-215.

Lombardo F (1999) Remarks on the genus Metriomantis Saussure $\&$ Zehntner and descriptions of two new species and a new genus: Rehniella gen. n. (Insecta: Mantodea). Revue Suisse de Zoologie 106: 393-405.

Lombardo F, Ippolito S (2004) Revision of the species of Acanthops Serville, 1831 (Mantodea, Mantidae, Acanthopinae) with comments on their Phylogeny. Annals of the Entomological Society of America 97: 1076-1102.

Menezes E, Bravo F (2013) Uma nova espécie de Orthoderella Giglio-Tos (Mantodea, Mantidae, Photinainae) do Brasil. Revista Brasileira de Entomologia 57: 12-18. doi: 10.1590/ S0085-56262013000100003

Nihei SS, Carvalho CJB de (2007) Systematics and biogeography of Polietina Schnabl \& Dziedzicki (Diptera: Muscidae): Neotropical areas relationships and Amazonia as composite area. Systematic Entomology 32: 477-501. doi: 10.1111/j.13653113.2006.00376.x

Otte D, Spearman LA (2005) Mantida species file, catalog of the mantids of the world. Philadelphia, Association of Insect Diversity, 489p.

Rafael J, Cumming J (2009) Revision of the genus Macrostomus Wiedemann (Diptera: Empididae: Empidinae). I. The ferrugineus species-group. Zootaxa 2064: 39-56.

ReHN JWH (1941) A new genus of Mellierid Mantid from Venezuela Orthoptera -Mantidae. Notulae Naturae, Academy Natural Science of Philadephia 70: 1-4.

Rivera J (2010) A historical review of praying mantid taxonomy and systematics in the Neotropical Region: State of knowledge and recent advances (Insecta: Mantodea). Zootaxa 2638: 44-64. doi: $10.11646 / \% 25 \mathrm{x}$

Rivera J, Svenson G (2016) The Neotropical 'polymorphic earless praying mantises' - Part I: molecular phylogeny and revised higher-level systematics (Insecta: Mantodea, Acanthopoidea). Systematic Entomology 41: 607-649. doi: $10.1111 /$ syen. 12178
Rodrigues H, Cancello E (2013) Mantodea (Insecta) collection in the Museu de Zoologia da Universidade de São Paulo: Taxonomic and geographical coverage. Check List 9: 957-965. doi: 10.15560/9.5.957

Roy R (2002) Révision du genre Néotropical Macromantis Saussure, 1871 (Dictyoptera, Mantidae). Bulletin de la Société Entomologique de France 107: 403-418.

Roy R (2014) A historical review of nomenclature and high-level classification of praying mantises (Mantodea), including a provisional checklist of the names associated to suprageneric ranks. Zootaxa 3797: 009-028. doi: 10.11646/zootaxa.3797.1.5

Roy R, Cuche T (2008) Catalogue du materiel type des mantes conserve au Museum d'histoire naturelle de Geneve (Insecta: Mantodea). Revue Suisse de Zoologie 115: 3-24.

Roy R, EHrmann R (2009) Révision du genre Zoolea Audinet-Serville (Mantodea, Mantidae, Vatinae). Revue Française d'Entomologie 31: 1-22.

Roy R, STiEwe MBD (2011) Révision du genre néotropical Orthoderella Giglio-Tos, 1897 (Mantodea, Mantidae, Photinainae). Bulletin de la Société Entomologique de France 116: 43-56.

Saussure H de (1871a) Mélanges Orthoptérologiques - IV. Mantides. Mémories de la Société de Physique et D'Histoire Naturelle de Genève 21: 1-214.

SAussure H de (1871b) Synopsis des Mantides Américains, p. 1-186. In: Memories pour servir a L'Histoire Naturelle du Mexique, des Antilles et États-Unis $4^{\mathrm{a}}$. Genève, George $\mathrm{H}, 186 \mathrm{p}$.

SAussure H DE (1871c) Mélanges Orthoptérologiques-Mantides. Mémories de la Société de Physique et D'Histoire Naturelle de Genève, Suppl. 3, fascicule 21, p. 239-337, Genève, Georg H.

Shevtsova E, Hansson C, Janzen DH, Kjaerandsen J (2011) Stable structural color patterns displayed on transparent insect wings. Proceedings of the National Academy of Sciences 108: 668-673. doi: 10.1073/pnas. 1017393108

Svenson GJ, Branham MA (2007) Case 3402: Photinini LeConte, 1881 (Insecta: Coleoptera) and Photininae Giglio-Tos, 1915 (Insecta: Mantodea): proposed resolution of homonymy between family-group names. Bulletin of Zoological Nomenclature 64: 1-9.

SVEnson G J, Whiting MF (2009) Reconstructing the origins of praying mantises (Dictyoptera, Mantodea): the roles of Gondwanan vicariance and morphological convergence. Cladistics 25: 468-514. doi: 10.1111/j.1096-0031.2009.00263.x

Terra PS (1992) Zelo materno em Cardioptera brachyptera (Mantodea, Vatidae, Photininae). Revista Brasileira de Entomologia 36: 493-503.

TERRA PS (1995) Revisão sistemática dos gêneros de Louva-A-Deus da região Neotropical (Mantodea). Revista Brasileira de Entomologia 39: 13-94.

TERRA PS (1996a) Comportamento sexual de Cardioptera brachyptera (Mantodea). Revista Brasileira de Entomologia 40: 3-7. TERRA PS (1996b) Zelo materno em Photina amplipennis Stål (Man- 
todea, Vatidae). Revista Brasileira de Entomologia 40: 9-10. Westwood JO (1889) Revisio Insectorum Familiae Mantidarum, speciebus novis aut minus cognitis descriptis et delineatis. London, Gurney \& Jackson, 55p.

Wieland F (2013) The phylogenetic systems of Mantodea (Insecta: Dictyoptera). Species, Phylogeny and Evolution 3: 3-222.

Yager DD, Svenson GJ (2008) Patterns of praying mantis auditory system evolution based on morphological, molecular, neurophysiological and behavioural data. Biological Journal of the Linnean Society 94: 541-568. doi: 10.1111/j. 1096-0031.2009.00263.x
Submitted: 22 March, 2016

Received in revised form: 20 May 2016

Accepted: 14 June 2016

Editorial responsibility: Ângelo Parise Pinto

Author Contributions: AAA conducted the taxonomic review; AAA and JAR analyzed the data and wrote the paper. Competing Interests: The authors have declared that no competing interests exist. 